PROSE

\title{
Jack
}

Katelin Farnsworth

\section{For Stevie $x$}

I WENT TO see Jack a week after he made the announcement. The afternoon was a lazy summer one, the sun sliding through the windows like egg yolk. The pale blue of the sky reminded me of a boy's first bedroom, or the streams of light found in glittering streetlamps, or the blue shadows that shimmer inside teacups. I don't know what I had been expecting, or even what I wanted to see, but what surprised me the most was how Jack didn't seem to have changed. He was still the same. He grinned, threading a lacy tablecloth through his fingers.

"G'day Elly," he said, kissing me on the cheek. "How you doin'? Had a good mornin'? Hungry? There's a plate of pancakes in the fridge."

It struck me how strange his comments were- and pancakes, hot honey tea with lemon frightened me. Such normality when everything was so different.

"What - what do I call you now?" My lips wobbled uselessly.

"Jack," he promptly replied. "Look, sit down Elly. I'm sorry I haven't told you all this - well ..." He waved a hand, "all this stuff, but I never knew what to say, ya know? Trying to suppress it all I guess. And I guess I've been afraid of not being accepted. It's hard."

My lip hurt from where I'd been biting it. "Yeah." A painting hung on the wall behind me. I turned to look at it. It was of two men holding one another, leaning into each other suggestively. I felt my skin prickle and wondered how I had never noticed it before. Jack stood and spread 
his arms out. His hair was clipped short, it always had been, but for some reason it had never meant anything. Now it suddenly meant everything. "I . . er . ..."

"Look, it's okay," he said, going over to the fridge and taking a carton of juice. "Nothing's really changed. I'm still me, ya know? It's just, I'm gonna be a different me." He took a long slurp.

"But-I liked you the way you were ..."

He stared at me, his dark green eyes flickering, and then shrugged his shoulders.

"Yeah? Well I didn't. That wasn't me. Being forced into the female toilets? Looking in the mirror and seeing these round lumps of fat? I was never meant to have boobs. And these fucking hips - they don't belong to me. All of this, it's not mine! It makes me feel sick." He motioned up and down and tugged at the flannel shirt he had on. I frowned. I had always envied his body.

It was the type that looked perfect in a two-piece bathing suit, slim and toned, round in all the right places. I wasn't ready to see him give it up. I remembered the way girls would ogle at him as he glided across the sand. We all wanted to be just like him.

"Bleeding between my legs every month? I'm not meant to be bleeding! I shouldn't have a god damn vagina but guess what? Some men have vaginas!"

I shivered. Outside I could see a cat stretching its back on the hard pavement, lolling its head and paws out into the sun.

"Being told I can't play with toy trucks or have blue pyjamas? That I need to grow my hair long and tie ribbons into it? No, that's not me. That was never me."

"Yeah but that stuff . . . all that . . . they're just clichés. We all know women can like whatever they want and do whatever they want. Aren't you just ... er ... you know, buying into gender roles and all that crap? Why don't you ... just . . you know, re-define what female means?" He frowned, narrowing his eyes. "Elly, you don't understand-"

"Monica-" I interrupted.

"It's Jack now," he said coolly.

I blinked. "Yeah, whatever, are you sure about this? I mean, how do I know this isn't just some 'phase' you're going through?

Like, you've never talked about any of this before. It's all a bit sudden, isn't it? I mean it's just come out of nowhere!" 
Jack slammed his fist into the table. The teacups trembled and I thought back to when we were kids. All those times we had played dress ups, wearing long stockings and flowery hats, painting each others nails and whispering under doona covers, giggling about the boys in the next house over.

"Listen, Elly - "

"No, you listen!" I said, raising a hand angrily. "How do you think I feel? We've been best friends for twelve years and you never told me any of this? And now all of a sudden you just expect me to be okay with this, 'I'm a man' crap? I mean, who the hell are you? Have I ever known you? What the hell, Monica? How can you suddenly just come out and say that you're a man?"

Jack put a hand on my shoulder. "I haven't changed, Elly." He paused. "Are you hungry? I'll make sandwiches." He took a spongy loaf of bread and began to cut it into thick, rough slices. His delicate hands shook. My insides squirmed. Monica had always been my best friend. Who was Jack? I didn't want to know.

"I'm going. I'll see you later."

"Can I call you?" he asked.

"No. I need time to think." I slammed out of the flat. I stamped my feet on the concrete, barely noticing the pretty chalk etchings I was trampling; yellow birds and dusty pink rainbows crumbling beneath me. The dying sun streaked across my face. A car pulled up.

"Hi, wanna ride?" a voice said. I kept marching.

"Hey honey," the voice said, "don't be like that. I just wanna have a chat. The name is Maza."

I swung round. 'Look, Maza, I don't know who you are. What do you want?"

The car came to a halt. A woman, draped in a shimmering blue dress, stepped out and smiled.

"I just wanna talk. I'm friends with Jack."

"Jack? What are you talking about?"

"Come now, don't be like that. He's still your best friend. Nothing has changed." She pulled her sunglasses down onto her nose, revealing smoky grey eyes.

"Oh!" I said, suddenly realising. "You're one of them, aren't you?" She laughed girlishly. "One of what?"

"One- one of those trannies!" 
"No, I'm not. But even if I were, why would that make any difference? Would that change who I am somehow?"

"I-I guess not . . . but Monica is different! Monica has been my best friend my whole life. She can't be . . . she's not a guy. She's just confused."

"Look, Jack really needs your support now. He's going through a lot. It's not easy to transition, even when you have a support system. He needs his friends around him. It takes immense courage to come out and finally let people know who you are."

I gritted my teeth together.

"Well, maybe," I finally said. "But-Monica has never shown any signs of, well, this stuff! She's always loved dressing up and going out, and we would always talk about the boys at school and I . . I don't know," I said lamely. "I dunno."

Maza stretched out a hand. I stared at it for a moment and then took it. Her skin was smooth.

"Who are you?" I asked, as she ushered me into her car. She pulled her sunglasses back up over her eyes.

"Me and Jack are dating."

"You and Monica? She's ... she's a lesbian?"

Maza shook her head. "No, honey. Monica is not Monica. Her name is now Jack - and she is not a she at all. Please try to understand. He needs you. Your friend needs you."

"Please stop calling Monica that! She's a girl!"

Maza re-applied her lipstick and started the engine. The car hummed forward.

"Let me drive you back to Jack's. Just talk to him honey, let him tell you how he feels."

I snorted. "Yeah, I already know how she feels."

I watched Maza's hands curl around the steering wheel deliberately. I wondered where Monica had met her. How long had they been at it? The sun was setting, light pinks and reds slushing together. Summer was on its way out. I wondered how long Monica had kept this secret from me.

"Let's go in," Maza said quietly as we arrived.

"I need time," I said. "I can't just go in there and pretend that everything is normal when it isn't. Don't you understand?"

"I'm sorry honey, I don't. Your friend needs you." 
I bunched my fists together. "Yeah, well, I'm not going inside."

Maza sighed. She unbuckled her belt and stepped out. "I'm not going to make you."

Inside, I watched shadows move about. I tried to look away, but my eyes were obsessed with the indistinct scene. I wondered what they were saying to each other. I twiddled my fingers nervously and wrapped a loose thread of cotton through them. Suddenly, as though some kind of invisible force had pushed me forward, I found myself standing on the doorstep.

"Elly," Jack said.

"Um," I said stupidly. "Hi."

He pushed a strand of hair out of his eyes. "Come in."

I didn't move. "So, you're- you're a guy," I said, my voice slipping into threads inside my mouth.

"Yeah," Jack sighed. "I can't make you support me, Elly. I can't make you understand . . . but I just want you to know that -" I shuffled my feet and stuck my hands in my pockets. "I don't know, Monica. I don't know if I can do this. I need time." Jack's face fell and he reached for my hand, squeezing it quickly. Tentatively I squeezed back. "I'll see you soon. I'm sorry," I said, turning into the darkness.

Somehow, even though I wasn't ready to access it all, I knew deep down that, just because everything had changed, it didn't mean everything was different. I turned around and walked back to Jack's. 